\title{
Mothers Construct Fathers: Destabilized Patriarchy in La Leche League
}

\author{
Linda M. Blum and Elizabeth A. Vandewater
}

This paper examines changing masculine ideals from the point of view of women homemakers through a case study of La Leche League, a maternalist organization dedicated to breastfeeding and mother primacy. We suggest two reasons for studying the League: first, an emerging literature suggests that changing norms are seeping into many such seemingly conservative groups, and second, the League continues to be highly successful among white, middle-class, married women. The paper looks at two aspects of masculinity, examining changes in the League through fieldwork, interviews, and content analysis, and finds that new norms of increased father involvement and decreased rights over women's bodies have both influenced League philosophy. We conclude that while in some respects a measure of the decline of men's patriarchal privileges, the League's changes also may contribute to a "restabilization" of male dominance in a modified, partial form.

In the past twenty-five years, both the economic restructuring of postindustrial capitalism and the resurgent feminist movement have radically disrupted modern patriarchal gender and family arrangements in American society. Such arrangements of female dependence on the male wage (or support in exchange for privatized domestic service), had been culturally dominant and relatively stable for a century or more, although never uniformly achieved or uncontested (Bernard, 1989; Kessler-Harris and Sacks, 1987). ${ }^{1}$ Social scientists have since documented the widespread

Linda M. Blum is Assistant Professor of Sociology, University of Michigan, Ann Arbor, Ann Arbor, MI 48109-1382.

Elizabeth A. Vandewater is a Doctoral Candidate, Department of Psychology, University of Michigan, Ann Arbor.

Please address all correspondence to the first author. 
influence of feminist, egalitarian tenets (e.g., Mason and Lu, 1988; Thornton, Alwin, and Camburn, 1983); according to a 1990 Gallup Poll, for instance, fully $57 \%$ of Americans now favor marriages in which partners share paid work and child-care (cited in Stacey, 1990, 303 n. 46). Moreover, while New Right voices exhort us to return to the "patriarchal bargain" (Kandiyoti, 1988), that exchange is now out of reach for much of the middle class thanks to the undermining of the male wage by corporate "downsizing," deindustrialization, and a sharply escalating cost of living. ${ }^{2}$ Analysts emphasizing women's autonomy applaud men's lessening dominance in families (e.g., Hartmann, 1987), but others find that for many women the destabilization of patriarchy in this "postindustrial deluge" has had a mixed impact (Stacey, 1990, 259). This paper adds to the literature on women's mixed responses to gender change through a case study of homemakers in a maternalist organization.

Because the threat to male breadwinning and manly honor now touches the white middle class (e.g., Newman, 1988), the examination of masculinity has reached new heights. The visibility of Robert Bly's book Iron John (1990), the media attention given to the Men's Movement, even the high ratings of the TV show "Home Improvement," indicate that the preoccupation with masculinity extends well into popular, mainstream audiences. ${ }^{3}$ In this study we examined changing constructions of masculinity and fatherhood from the point of view of mothers, and we suggest two reasons for such a strategy. First, as R.W. Connell et al. suggest (1989: 585 ), much of the literature on masculinity emphasizes men's sex role oppression, their need for personal transformation and new forms of male solidarity - women often drop out altogether, and men's continued social dominance is ignored (also Kimmel, 1992). We suggest that because women still contend with the disproportionate share of caregiving, kin-making (Laslett, forthcoming), and domestic work (summarized in Wright et al., 1992), as well as social subordination, women's responses to changed masculine norms must be considered. Second, because gender is always relationally constructed (Connell, 1990), ideologies of motherhood that have powerfully shaped women's subordination must be seen in relation to equally powerful ideologies of masculinity, fatherhood, and dominance.

We explore mother's constructions of fathers through a case study of La Leche League, an organization dedicated to "good mothering through breastfeeding." At first, this group looks like a worst-case scenario for gender transformation. The League was founded in the celebrated domesticity of the 1950's by seven Catholic women committed to extended, on-demand breastfeeding, natural childbirth, and large families, literally embodying the assumptions of exclusive, intensive motherhood and female economic de- 
pendence. While officially nonsectarian, the League was named after "Nuestra Señora de la Leche y Buen Parto," Our Lady of Happy Delivery and Plentiful Milk (LLLI 1987). As the sole-provider ideal has collided with postindustrial capitalism, however, the League has moved to a partial accommodation of the two-paycheck family. Moreover, as Judith Stacey argues (1990), recent research finds evidence for changing gender ideology and the influence of feminism in many such unlikely locations. These include evangelical Christian groups (Stacey, 1990), among students in evangelical colleges and seminaries (Hunter, 1987), among women turning to Orthodox Judaism (Davidman, 1991; Kaufman, 1991) and even among women in antiabortion groups (Ginsburg, 1989). Studying La Leche League adds to our understanding of both why women are drawn to such traditional settings (even as they may also selectively draw on feminist tenets), and how such groups face the changing environment.

An additional reason for feminist scholars to examine La Leche League is quite simply its success (also suggested by Gorham and Andrews, 1990). Premised on exclusive motherhood, the League nonetheless attracts thousands at a time when most mothers of infants are returning to the paid labor-force, ${ }^{4}$ and most adults report approval for this trend (Mason and $\mathrm{Lu}, 1988$ ). La Leche League, in fact, was recently cited as second in size only to Alcoholics Anonymous among self-help groups in America (Brighton Argus, 1991). One reason is fairly straightforward: the League remains the major source of practical breastfeeding advice (now advocated by the medical profession and popular among the white middle-class, breastfeeding remains outside the expertise of most physicians)..$^{5}$ If the group now helps employed women to breastfeed, its main activity remains offering support groups that promote an intensive style of mothering in conflict with multiple roles and gender egalitarianism (we examine these conflicting ideologies of motherhood in Blum with Vandewater, forthcoming). However, the group reports 12,000 leaders, 33,000 paid members, and contact with some 100,000 mothers per month (phone communication 1992). ${ }^{6}$ And the League's manual, The Womanly Art of Breastfeeding, has sold over two million copies.

\section{METHOD}

This study is based on three sources of qualitative data, reflecting the multiple levels of League discourse and our dual research questions. (1) The first author conducted participant observation fieldwork, attending repeated meetings of three local groups, to examine how the League ideology 
was employed by leaders and participants in group settings. The local groups drew from affluent and working-class areas. (2) The first author also conducted twenty-four in-depth interviews with participants, particularly scrutinizing how individual's views might vary from the organization's stance. Twenty respondents were drawn from volunteers at the local meetings, with an additional four recommended. Of the twenty-four, nine were leaders and fifteen were nonleaders. The tape-recorded interviews took place in the respondents' homes, averaging two hours. (3) Finally, both authors analyzed League publications representing the organization's formal ideology. This was supplemented by participant observation attendance at a statewide conference, as well as several informational phone conversations made to the national headquarters.

We analyzed League publications on fatherhood utilizing an episodic or vignette method, content coding the text by brief, thematic meaning units usually about one paragraph in length (Sears and Lapidus, 1973). This method was well suited to League publications as many are written from strings of brief personal testimonies. We analyzed two years (1990-92) of the "Focus on Fathers" column in the bimonthly members' magazine, chapters on fatherhood from three editions of the League manual $(1963,1981$, 1987) and several League advice books, and a random sample of pages from each chapter of Becoming a Father (Sears, 1983), the one League book devoted exclusively to the topic.

Our interview sample, while not representative, reflects the white, middle-class base of the organization. Access to a white male breadwinner has long divided American women, but at present it represents an even sharper axis of stratification. Women in La Leche League tend to fall on the high side of this racialized gender/class divide. As Florence Andrews notes in her field study (1991: 95, n.6), few low-income or single mothers are drawn to the League because the "intact" family is so central to its philosophy. Of the 24 women interviewed, all were in "intact" marriages. Most of the husbands had college degrees or better, and those few with blue-collar jobs were in the dwindling number still providing a "family wage" and benefits. The median income of these men was about $\$ 40,000$, but this included a wide range from $\$ 20,000$ to the high-end outlier of $\$ 100,000$. Women drawn to the League include the affluent and those struggling to cover their house payments, but most share a "good enough" male provider to at least cut back on paid work during their children's early years. Nonetheless, over half the women interviewed did some work for pay: three were fully sharing breadwinners, six had regular parttime jobs, seven worked occasionally or very parttime (less than 10 hours per week), and one was a fulltime graduate student, leaving just seven fulltime 
homemakers. ${ }^{8}$ Only one interviewee was African-American, specifically referred to us when we questioned the lack of racial diversity in the League; she was also one of the handful of women of color observed at the statewide conference, among several hundred families in attendance.

\section{DESTABILIZED PATRIARCHY}

Studying American men, Joseph Pleck has concluded that fulfillment of the breadwinner role remains central to self-esteem and identity; he contends that the postindustrial undermining of that manly status will ultimately be as or even more consequential than feminism (1989: 596). Connell agrees, though without weighing the two factors, that hegemonic masculinity is threatened (1990). According to economists, in fact, actual wage and salary levels for most male earners, blue- and white-collar, have steadily deteriorated in the last fifteen years (Kuttner, 1992). ${ }^{9}$ Despite this threat to the social organization of male dominance, we use the term "destabilized patriarchy" with some hesitation, meaning only that the modern basis of masculinity has been shaken up or disrupted rather than that male dominance is over. Destabilized patriarchy opens up possibilities for gender transformation, but (as several astute reviewers pointed out) this could lead to modified or "retrenched" forms of patriarchy. In itself, this possibility makes the study of nostalgic or backward-looking groups like La Leche League quite interesting; and the League may be one of the few groups promulgating family advice to a largely secular audience.

From the literature on such traditional groups, two themes of changing masculinity stood out. First and most striking, men's increased involvement in domesticity is now viewed as highly desirable, and the Involved Father competes with the Good Provider as the dominant ideal. Both Stacey and Hunter, for example, found that younger cohorts of Evangelical Christians place a high value on male responsibility for childcare and have relatively flexible, quasi-androgynous attitudes about household work (Hunter, 1987, 106-114; Stacey, 1990, 267-268). We wondered though how mothers drawn to a maternalist rather than religious organization responded to changing norms for fathers. Most of these women revealed a divided stance: influenced by the participatory feminist objectives, they nonetheless emphasized the father as provider and their own continuing primacy as the mother. As an organization, the League may be providing a haven for such women by supporting or normalizing conflicting gender ideals. We take up this issue in the first section in our discussion. 
The second theme of destabilized patriarchy is deeply contested among traditional groups: women's rights to bodily autonomy, and to autonomous, nonprocreative sexuality. In one sense La Leche League has always expressed a woman-centered "politics of the body" in both the resistance to medicalized motherhood and suggestion of the sensual pleasures of breastfeeding. However, both were still patriarchal in that ultimate rights in the mother's body rested with the husband and father, and positive notions of sexuality never extended beyond heterosexual marriage. Stacey (1990) argues that feminism has had an impact among such patriarchal groups, nonetheless, at least in combatting men's "aggressive heterosexuality" (Connell, 1990); feminist critiques of wife battery, marital rape, male toughness and repressed emotionality, which valorize women's rights to bodily self-determination and distinct sexuality, have influenced evangelical groups. We wondered, therefore, if such issues had influenced League ideology and participants, and disrupted previous masculine, patriarchal rights over women's bodies. We take up this issue after the discussion of the Involved Father.

\section{THE INVOLVED FATHER}

The concern with father involvement is not new for this mothers' organization. La Leche League has always emphasized the need for the father, for example, early on advocating the need for his presence during childbirth. Yet, in the past, a father's place was treated as in Parsonian sociology (Parson and Bales, 1953). The League advocated that the father should be the instrumental leader, the protector and provider, standing outside (and above) the mother-child dyad. Moreover, because men cannot breastfeed or produce the "mothering," lactation hormones (which purportedly make women more relaxed and responsive to their babies), fathers were considered "naturally" inadequate to fulfill the mother's expressive function. Because of the centrality of both "separate spheres" and biological rhetoric in past La Leche League discourse, we coded the literature on fatherhood on these two issues. Vignettes about fathers were coded as "secondary" if the father was portrayed as a separate, secondary parent, and as "equal" if he was portrayed as an equally responsible, expressive or nurturant parent; and episodes explaining gender or the father's role were coded according to the use of biological, social, or contradictory rationales.

At first glance, we could see that League literature had been influenced by notions of changing masculinity: comparing the three versions of the manual's chapter "The Manly Art of Fathering," we saw that the 1963 
heading referring to "Father as Provider and Protector," had been coupled with a new heading "Getting Involved" in the 1981 edition (1981: 148); by 1987 the patriarchal "Provider and Protector" had been replaced altogether. Now "Fathers Get Involved," and become "Husband and Wife-a Parenting Team" (1987: 195, 201). ${ }^{10}$ Assessing the coding results for 1981 and 1987 versions, however, we found a surprising lack of coherence in fathering ideals in the many conflicting testimonials. ${ }^{11}$ In our random sample from Becoming a Father (Sears, 1983), while 35 vignettes portrayed fathers as equal caregivers, 27 portrayed men as secondary Parsonian fathers, and similar divisions were found in the other advice books analyzed. The vocabulary itself is contradictory: "mothering" is used along with some use of the gender-neutral "parenting." The statewide conference illustrated this turn toward the androgynous: the organization's logo of mother and baby at the breast was modified to include a father, and the slogan emblazoned on tee shirts read: "Parenting-a Proud Profession."

Biological explanations of gender difference are still pervasive in League literature, yet they are frequently contradicted. In the book on fatherhood, 38 episodes invoked biological difference, while 25 used social construction arguments denoting gender malleability, and 7 were contradictory within the same vignette; and, similar divisions were found in the other materials analyzed. For example the manual states: "In language that is irrefutable, biology makes it clear that the mother-baby relationship is primary and should not be set aside" (LLLI 1987: 195). While this statement stood alone in 1981, by 1987 an expert is first cited who contradicts: "Although mothers do indeed have a hormonal head start ... I believe fathers also have natural nurturing abilities ..." (1987: 194). We saw a similar divided stance toward changing masculinity in our interviews. Women drawn to the League found it hard to reconcile conflicting desires for father involvement and for continuing primacy as the mother, as they found it hard to reconcile notions of (socially constructed) "parenting" with the biologism of the emphasis on breastfeeding itself. As a result, genuine if somewhat confused attempts to draw fathers into early caregiving and domestic work were combined uneasily with the sense of the exclusivity of the breastfeeding relationship. While participants varied, most held on to some belief in "natural" maternal advantage; yet all but six described their husbands as very involved fathers, "wonderful with the children," "very close to our girls," or even adding, "he's much better than most men that I know." We saw just two cases in which the father was responsible for as much infant care as the nursing mother, but in several others fathers contributed significant amounts of infant care, juggling schedules to provide care while mothers worked outside the home. The following comments regarding mother-primacy, however, were typical: 
Only a mother can give what a child needs, nobody else can, not even a father. A father can give almost as close, but only a mother can give what they really need.

I hate to make gross generalizations that all women are just naturally more nurturing. But I think, for the most part, that women are more nurturing than men.

I think biologically, men are just not as tuned in about little kids. Even a "Mr. Mom."

Yet women also expressed more combative sentiments, for greater equality in "parenting," such as the following:

It's terrible when you hear talk about husbands "babysitting"-we've got to train them to not think of themselves that way! They'll say, "does that mean I'm babysitting the children?" "NO, YOU'RE NOT-YOU ARE JUST DAD!"

The following testimonial written for the member magazine exemplifies the mixed response many League women have to gender-egalitarian "parenting" arguments that conflict with mother-primacy:

Just a year ago I thought that mothers and fathers were equally qualified to take care of infants . . . [but] [a]ny women who is awake and aware during the birth of her child and who feeds the child from the substance of her own body cannot believe that her feelings for the child are the same as the father's (Tamm, 1987). ${ }^{12}$

Interestingly, feminists are also sharply divided on such issues of "mothering," "fathering," gender difference, and the importance of biology. Such divisions were exacerbated by the Baby M and other surrogate mother cases, which devalued pregnancy, birth, and women's embodied experiences while honoring the rights of fathers (see Rothman, 1989). In a study of shared-parenting couples, Diane Ehrensaft also suggests that breastfeeding is difficult for equality-oriented feminists. Among the families committed to androgynous parenting, a significant number of mothers stopped breastfeeding very early owing to resentments and anxieties aroused by the exclusivity of the nursing relationship (Ehrensaft, 1990a: 37). In contrast, other feminists assert the primacy of the mother and the special interdependence of the mother-child relationship, striking similar chords to the philosophy of La Leche League. Difference-oriented strands of feminist theory, however, vary from an emphasis on socially constructed gender difference (e.g., Chodorow, 1978), to positions veering close to the biological determinism of La Leche League (e.g., Rossi, 1977; Ruddick, 1990; see Kahn, 1989 for an extreme example).

Despite the emphasis on maternal primacy, questions of father involvement receive much attention at local $\mathrm{La}$ Leche League meetings. Leaders often ask the group: "Anyone have suggestions on the Dads, how to make them feel included, how to share this time with them?" Responses typically range widely, as for example at one meeting: one fulltime teacher offered an egalitarian suggestion for sharing midnight feedings, but several 
laughingly offered stories of male ineptness and immaturity. Finally, one working-class woman complained:

My husband is into that GREAT PROVIDER thing, so he took a second job so that I can stay home . . . But I wish he was home more for me, and to hold this little one [their two month old son] so I could have five minutes to myself! [Sometimes] he does take our older boy, like to wash his car and that kind of stuff.

But ...

The leader quickly redirected this complaint by approvingly saying: "So he gives you space to mother?"- exemplifying the League's divided stance toward fathering. For while he may "give her space to mother," he was scrambling to work night shifts, overtime and a weekend job, and was almost never home to father. She was also well aware that both his paychecks did not add up to a modern breadwinning standard as she complained (in our interview) of being unable to purchase a home, owning just a small mobile home. Moreover, his were not the only paychecks in the family-she was employed for 3 evening shifts per week. This woman seemed to sense that she was losing on both ends in the "postindustrial deluge" (Stacey, 1990: 259), having neither the Manly Provider nor the Involved Father.

For the less affluent women in the League whose husbands earned below the group median such feelings of resentment seemed common. Lacking the traditional and the new masculine ideal in their marriage partners, they found mutual support at League meetings; but this did not have a feminist consciousness-raising impact. Rather than placing shared complaints in a social or political context, the League approach diffuses anger by emphasizing a positive, individualized interpretation. League ideology values compromise and diminished expectations, and celebrates small concessions that can keep marriages "intact." Another League participant, struggling to remain middle-class, illustrates the diminished expectations strategy:

I think in [League] there's a deep commitment to putting the child first. And tied up in that is money and valuing people before things . . . and I need to go back and be reminded and supported. [League meetings] are like a shot in the arm ... [because] I grew up with a lot of nice things. And it's real hard because of the man I married and his profession that I have had to do with a lot less... And that all ties in with my struggle of working or not working and my image of myself as a mother ... [I had] that idea, you know, that the husband is supposed to bring home ALL the bacon. ${ }^{13}$

This woman framed her story as one of individual downward mobility and, inspired by the League, she tried to reconcile herself to her marital choice and renounce her materialistic values. However, she was visibly resentful of her husband's failure of manliness and admitted having serious marital problems. (Like the GREAT PROVIDER, this father was also absent a great deal, and the family's unfinished home addition provided a visible, 
irritating reminder of this. ${ }^{14}$ ) Missing from this League-inspired frame is a larger political understanding of why her paid and unpaid labor have become a household necessity, as well as any notion of possible social change other than in a nostalgic, backward-looking direction.

As in such households, fathers are largely absent in La Leche League activities. Most notably, the structure of local group meetings includes none for fathers, with support groups strictly for mothers and babies. Fathers are welcomed at the state and national conferences, and groups may plan events to include them like yearly picnics, but these are strictly "extracurricular." None of the groups we observed were planning such events, although a substantial number of men were seen at the state conference, perhaps one-third of those attending.

League women were also struggling with how much fathers should share in housework. Even though many want their husbands to be the Good Provider, the extent to which an egalitarian, feminist norm of shared housework had been incorporated was still striking. For example, one woman stated: "It's hard because I don't think it's fifty-fifty." Official League ideology lends some support for sharing housework, as publications directed to employed mothers in particular use feminist-influenced arguments (Dana and Price, 1987: 44; Lowman, 1984: 154). ${ }^{15}$ Dividing housework was difficult for those in our sample who had cut back or quit paid work but still wanted a flexible gender division at home, as one member mentioned:

It's real hard to redefine what you feel comfortable with, what you should do, what you shouldn't do. And if you're staying home fulltime, how much should you take on?

Another, married to a construction worker often working 6 day weeks, said emphatically:

I do pretty much everything. .. If there ever comes a time when he's off work or slowed down, I'd expect him to help. I'd probably have a hard time getting him to do it, but I would expect him to do more than he does now, that's for sure!

Another League participant summed up the conflict in expectations and rights quite well stating: "It's not like MY JOB, but I guess it's my job, you know?" In late twentieth century America, we have moved beyond simply assuming that housework and childcare are a woman's exclusive responsibility, yet women still find themselves doing an inordinate share of the dirty work (Hochschild, 1989; Wright et al., 1992); and even homemakers like La Leche women question this gap between popular rhetoric and reality. Similarly, while men's actual participation may not have changed much, the interpretation of it has, with a newly inflated cultural value affecting even groups nostalgic for modern patriarchy. Women in La Leche League, with conflicting masculine ideals, seemed to construe their hus- 
bands as both traditional providers and participatory fathers even if that interpretation strained reality and masked resentment.

British psychologist Lynn Segal (1990), who surveyed changing norms of masculinity, also observed that the feminist movement has deeply changed ideals of fatherhood. Even in the home-oriented 1950s, the masculine ideal prescribed a father who disrupted the mother-child bond only with older children, mainly older sons. Currently Segal finds a paradoxical situation somewhat like that of women in La Leche League; although men place a high value on involvement, fathers tend to take over the more pleasurable activities and leave women with the routine, the dull, and the dirty (1990: 33-35). ${ }^{16}$ Some women may even seize upon breastfeeding, motherprimacy, and biological rationales as subtle, individual forms of resistance to such male usurpation.

The League's divided stance toward father involvement faces its most severe test when divorce threatens the "intact" family. Here maternalism clearly wins out. The League has become formally involved in the divorce issue in the last decade, ostensibly because physical separation of the mother and child threatens extended, on-demand nursing, but also because the primacy of the mother is challenged by joint custody or even liberal visitation settlements. Interestingly, the League maintains that it is a single-issue, nonpolitical organization, but its larger stake in national family politics is revealed in its growing involvement in the divorce issue. The group now offers advice to women on child custody and visitation agreements, as well as legal referrals, expert witnesses, and case documentation to protect the child's maternal attachment (see Breastfeeding Rights Packet 1986; Lofton and Gotsch, 1983; and Trimm-Harrison, 1991 for an illustrative story). We spoke with one national leader who counseled divorcing mothers:

It's just horrendous! We think that there should be visitation, but that there should be short, frequent visits until the child is older. They say it's all about allowing the baby to bond with the father, but these children don't have a strong bond with the father. And if the child is grieving for the mother, how can it have a relationship with the father?

Again, the divided feelings about father involvement and fathers' rights in the League are not easily dismissed, and in many respects, mirror divisions among feminists. Ehrensaft, in an astute essay on feminism and fathers (1990b), admits that the push for greater father involvement has had unforeseen negative consequences for women and children, although she retains the long-run ideal of shared, androgynous parenting. In a society that continues to value men over women, the insistence that men can mother can be used against women; and this happens particularly in divorce cases. ${ }^{17}$ Similarly, Sara Ruddick argues that while the ideal of father in- 
volvement may be nice, evidence of a "myriad of father problems" from absence and lack of support payment to violence and abuse is overwhelming, constituting the unfortunate reality (1990). Such arguments are troubling to equality-oriented feminists in their return to the association of women, nurturance, and nature, and the straitjacket of romanticized motherhood (e.g., Laqueur, 1990). However, as Ehrensaft writes, feminists of all strands must distinguish between perhaps the minority of cases in which "father involvement is in a woman's (and a child's) best interest, and when it is potentially destructive, given the social fabric of U.S. society" (1990b: 74). In its rejection of a larger political analysis or push for collective action, La Leche League's maternalist ideology clearly is not feminist, but it does usefully highlight this "equality-difference" dilemma in feminist theory. Emphasizing women's difference can sometimes better address that women are not, at present, similarly situated to men; yet La Leche League, like an extreme version of the difference-oriented strands, reinforces present gender distinctions and risks perpetuating women's exclusive responsibility for childrearing.

\section{FEMINISM, MEN, AND WOMEN'S BODIES}

Another aspect of feminist ideology which has reverberated deeply through mainstream culture, and La Leche League as well, is the demand for women's right to bodily integrity. Although under some attack at present with more restrictive abortion laws and fetal rights cases (precisely because it is an attack on patriarchical control), the general notion of bodily self-determination, particularly for white, middle-class women, has been deeply influential. La Leche League to some extent prefigured this, affirming the need for a woman-centered knowledge of our embodied experiences. With their advocacy of natural childbirth, breastfeeding, and "mother to mother" support, they rejected the technological intervention and male authority of the dominant "medicalization of motherhood" much as later feminist groups would (Van Esterik, 1989), (although well within the bounds of the coercive pronatalism of the era).

However, differing markedly from a feminist perspective, in the past the League espoused very traditional notions of masculine rights over female bodies. Stemming partly from the Catholic religious beliefs of the original founding mothers, the League accepted the father's dominance over the mother's childbearing and rearing decisions and his right of access to her body. Sociologists Gorham and Andrews write that the League assumed men would have difficulty supporting breastfeeding because it so 
threatened their access; in the past the League encouraged wives to try persuasion and "clever" ways to change his mind, but ultimately, she was told not to contradict his wishes (1990: 250). Interestingly, the assumed male aversion to breastfeeding may also have had some Catholic origins. Historian Valerie Fildes notes that in early modern Europe, Catholic countries institutionalized wetnursing because of the strong beliefs that lactating women should not have intercourse but that a husband's conjugal right to his wife's body was primary (1986:105, 121, 152-167).

In spite of these sexist origins, attitudes among League women toward bodily integrity today seem different, with women expecting a self-determination that reflects the influence of feminism and its partial destabilization of patriarchal privilege. One La Leche Leader illustrates this with the use of feminist, pro-choice rhetoric to describe how she came to breastfeed:

\begin{abstract}
I was five months pregnant ... and he [her husband] happened to casually mention: "well, have you given any thought to whether you are going to breastfeed or bottlefeed the baby?" And I looked in shock, "Well of course I am going to bottlefeed" .. . [breastfeeding] struck me as a really repulsive idea . . . But he said "Well, look, it's your body." And I said "That's right, IT IS!". . . I really made up my own mind and I was real adamant about MY body and MY choice.
\end{abstract}

When we asked these women how breastfeeding had affected their body images, in fact half responded that the impact was very positive or empowering. Several added that this was because their experience countered the predominant experience of breasts as sex objects, again showing the influence of feminist arguments. The following comment is a good example:

Our society is so moody in the way that breasts are viewed, and that's always bothered me. I really enjoy seeing my breasts as having a use. I like that a lot. I feel far more comfortable, and it's become far less of a sexual thing.

Such comments also came up in group meetings where women talked about feeling more relaxed, respectful of their bodies, or happier with their breast size since breastfeeding. One interviewee explained:

The first La Leche meeting that I went to, a woman was talking about how her body image totally changed when she started breastfeeding, and she came to have a more positive image of her body. And I remember thinking "Wow! She's echoing my sentiments exactly."18

Interestingly, many of these women made a connection between this positive experience of the body with being less sexually available to their husbands, in particular realizing that their breasts had become "off limits." As one put it, breasts become less "sexual objects" than "nurturing objects." One leader nursing a toddler explained: "it's gotten to the point where if [my husband] touches my breasts, I instantly go like this [flinching] because I just don't want it." Others mentioned that it was more than just their 
breasts which were "off limits:" they may lose sexual desire altogether. One League mother spoke of this at length:

The sex issue was a real issue for my husband and I after having the kids. I'm just not interested and I really feel that I'm giving so much of my physical being all day long with nursing, with carrying children around, that by the time my husband comes home ... I just want to be all alone ... I don't want to have anyone touching me or, you know, that's when I get possessive of my body. So that has been difficult for us and I think it's difficult for a lot of women .... Everybody's afraid to admit that they aren't interested in sex . . because all the magazines have told them that you're supposed to be having sex every night.

From a feminist perspective it seems positive that this League member would so readily speak of her lack of desire; and the fact that she put her own needs at least on a par with her husband's could be seen as a positive outgrowth of feminist critiques of male sexuality. However, the lack of autonomous desire may give feminists pause; La Leche League's ideology may also encourage women to consign their breasts and bodies over to their babies as much as for themselves. One young leader, in fact, discussed just this kind of conflict about bodily autonomy and sexuality:

Sometimes there is a conflict. And I really feel physically violated, especially when my son paws at me; I mean, I just can't express it any other way. . . . Then of course, at the end of the day when my husband gets a little romantic, I just feel like "don't touch me!" Or at least leave my breasts alone.

Yet she went on to explain that while belonging less to her husband and at times too much to her babies, her sense of her body was still much more positive since breastfeeding:

Overall I think the nursing relationship has enhanced my sexuality in the sense of making me feel more comfortable and that my body is more valuable and beautiful in a way that I had not realized before.

The brief discussions of maternal sexuality in the League manual and several other advice books we examined suggest such a multiple interpretation. On the one hand, League literature seems to reinforce patriarchal norms constraining women's autonomous sexuality; for example, while trying to reassure women that varied experiences of sexuality are normal, the manual advises:

It isn't fair to put your husband and children in competition with each other for your time and affection. Whoever has the greatest need at the time for love and affection receives it (LLLI 1987: 118).

On the other hand, some discussions suggest possibilities beyond this patriarchal construction. For example:

[you] need to have the final say over the use of your body ... you know you can fall into the arms of a man who, if you ask, will cradle you and not insist on making more physical demands on you ... there is sometimes no stronger aphrodisiac than 
being given Jove by a man who is not expecting to make love (Bumgarner, 1982: 75-76).

The League hardly goes so far as to renounce the tie to procreative sexuality implicit in the valorization of breastfeeding and birth (nor does it go nearly as far as the feminist valorization of gay and lesbian sexualities); yet League ideology does come close to espousing a "feminized" ideal of heterosexual intimacy popularized by the women's movement (Cancian, 1986). ${ }^{19}$ And while the group's ideology is still somewhat conflicted, our participants' sense of rights to their bodies as compared to their husbands' indicates both the impact of the women's movement and the depth of recent upheavals of masculine norms. In fact, when the first author asked one twenty-year League veteran, a self-identified feminist, about changes she had witnessed, she replied quickly:

The dads, OH that's the BIG change from twenty years ago! I can't tell you how many people twenty years ago would say "I want to nurse but my husband really doesn't want me to," "My husband says l'm nursing too much." And my husband this and my husband that. . . So maybe we got the men along a little bit farther... That's good!

\section{CONCLUSION}

In this paper we have explored divided constructions of manhood and masculinity within a maternalist organization for two reasons: changes within such unlikely locations provide interesting evidence of the disruption of the modern gender/family order, while the League's continued success illuminates women's mixed responses to these postindustrial capitalist upheavals. Clearly the League speaks to deeply felt needs among many white, married mothers. For such women, the League supports or normalizes divided, contradictory constructions of both the good mother and the good father, but it retains the notion of the primary importance of the mother through the biological essentialism of breastfeeding. For many women in postindustrial America a retreat from such maternalism may offer little im. mediate gain either in the home or workplace, and so League philosophy may seem to offer more than popular conceptions of equality-oriented feminism. But women's attraction to such backward-looking groups shares similarities with some difference-oriented feminist strands in which, "the urge to protect biological motherhood stems partly from the desperate need to find a secure and defensible basis on which to reassert mothers' claims" (Stanworth, 1990: 298) in the postindustrial or late capitalist context. Even these maternal-identified women, however, have been deeply influenced by 
feminist attacks (of many strands) on men's patriarchal privileges. Like other women nostalgic for modern patriarchy, La Leche women selectively adapt ideals for fathers' increased participation in the family and for his decreased rights to control and define her body and sexuality.

As an organization, a group like La Leche League shows the extent to which the norms of modern patriarchy have been shaken up. Yet, at the same time, the League's accommodations to the changing environment indicate the strong possibility for a "restabilization" of patriarchy in a modified form. The family advice promulgated by the League has changed, but it endorses feminist principles only when used in very privatized ways that discourage notions of collective efforts or public provisions for gender equality. The League encourages women to remain married, and to diffuse resentment toward their husbands, who may fall short of new and old constructions of ideal masculinity, by diminishing their expectations and inflating the value of their husbands' contributions. The organization's ideology valorizes token efforts at "involved fathering" rather than arguing for more thoroughgoing changes, leaving women in partial economic dependence with the predominant if not exclusive responsibility for childrearing. This may contribute to a "retrenched" vision of a modestly role-sharing but far from egalitarian family, one which leaves men more flexible but still dominant.

\section{ACKNOWLEDGMENTS}

For financial support, we acknowledge the University of Michigan Rackham Faculty funds. Pat Preston very ably managed the interview transcription process. Julia Adams, Marty Whyte, members of the Family Studies Seminar of the University of Michigan, and the anonymous reviewers for Qualitative Sociology provided valuable criticism. An earlier version of this paper was presented at the annual meeting of the American Sociological Association, Pittsburgh, PA, August 1992.

\section{ENDNOTES}

1. For an interesting account of the stabilization of modern patriarchy in 19th century Britain, with the emergence of both an individuated wage form and the male breadwinner norm, see Seccombe, 1986.

2. This late twentieth century political-economic stage is referred to by a variety of labels: postindustrial, late capitalist, postfordist, etc. I rely on economic sociologist Fred Block 
(1990) (as does Stacey, 1990,18) who uses the term postindustrial to designate a particular form of capitalism characterized by the loss of good-paying industrial jobs, growth in low-wage, contingent service-based employment, and an increasingly two-tiered society. (Also the collection in Eitzen and Baca Zinn, 1989.)

3. Iron John appeared on national bestseller lists for months; the New York Times Book Review included the paperback edition for 14 weeks (May 31, 1992, p. 42). A computer search of popular magazines revealed 37 articles on Bly and the men's movement, with 31 appearing in the last two years; titles include: "It takes more than balls to be a man" (Esquire October 1991 cover story), "White guys with drums" (Gentlemen's Quarterly December 1991), and "In search of a masculine mystique" (Fortune January 1991). The television sitcom "Home Improvement" derives its humor from the theme of threatened masculinity while mildly spoofing "Iron John."

4. In contrast to earlier eras, postindustrial capitalism has seen a dramatic increase in the labor force participation of mothers of young, preschool-age children, and of mothers of infants in particular. In 1977, only $32 \%$ of mothers of infants were in the labor force, but by 1987 , this had increased to fully $52 \%$ (US Dept. of Labor 1987; 1990: table 48 ). The labor force participation of this group doubled between 1970 and 1985 , representing the most rapid increase of any group of women; and for most this employment was fultime (Hayghe, 1986).

5. Breastfeeding sharply declined in the post World War II era, resurging only in the late 1970 s. While the sources of this change are not entirely clear, the medical profession's endorsement seems more consequence than cause, and the feminist rejection of medicalized childbirth may have been a more significant impetus (see Blum, forthcoming; Van Esterik, 1989). Currently just over half of all mothers breasifeed at birth, but differences by race and class are striking with the practice most popular among white, middle to upper class women. League women differ most from middle-class norms in advocating extended breastfeeding, for several years per child; in contrast, only $18 \%$ of American mothers continue breastfeeding for six months (Ryan et al., 1991).

6. Like Alcoholics Anonymous, precise numbers do not exist as paid membership is never required for participation in support groups. However, the League is a centralized, hierarchical organization with a national staff that accredits all local leaders, sets formal policies, runs conferences and fund-raising projects, and publishes numerous materials from medical research to parenting advice manuals (Gorham and Andrews, 1990).

7. My son was still an infant during the fieldwork, and partially breastfed although not according to the League's ideal practice. I was able to "pass" as a participant, but the organization and local groups knew of my research.

8. Median household income was about $\$ 45,000$, substantially above the national family median of $\$ 35,500$ (cited in Kilborn, 1992).

9. Average household income has risen slightly only because of the increase in two-paycheck families (Kuttner, 1992).

10. In the 1963 chapter, "Father as Provider and Protector" was one of four headings, boldly highlighted and set-off to introduce chapter sections; in 1981, we have mentioned two of seven, and in 1987, two of six. Other headings were less relevant such as: "Communicate Your Feelings" or "The Rewards are Great."

11. Surprisingly, there were not more vignettes portraying fathers as equally expressive caregivers in the 1980s, although the packaging in headings and photos certainly emphasized a more participatory, involved image for men. However, there was a clear shift away from the exclusively biological explanation for gender difference found in 1963.

12. One member's testimonial (from Lowman, 1984) captured the conflicting desires well. After a year's leave of absence, this mother returned to work while her husband shifted to a parttime schedule and took on more childcare. This is framed very positively ("My husband's co-workers congratulate him on his commitment to fathering"), yet the story ends with the line: "But I do wish I could be the one working part-time" (1984: 154).

13. As mentioned earlier, we discuss such work/family conflicts of League mothers in great detail in Blum with Vandewater, forthcoming. 
14. When I arrived for our interview, I complimented her on the remodeling, remarking that it would be impressive when completed. She snickered, because the project had remained unfinished for years.

15. For example, one advice manual comments that "study after study" has shown continuing inequity in the division of housework, citing Harris Poll figures of women's paid and unpaid labor totalling 85 hours per week compared to men's 65 ; the authors emphatically comment, "it's time for a change!" (Dana and Price, 1987; 44).

16. Other researchers concur; see Biernat and Wortman, 1991.

17. Although the percentage of contested custody suits is very small, fathers win in approximately two-thirds of such cases (Ehrensaft, 1990b: 74, n. 29; also Weitzman, 1985). Moreover, as Michelle Stanworth writes, legal battles are only part of the story; numerous uncontested custody and access agreements are made under partially coerced or anxious conditions because of women's vulnerability (1990). On this issue see Lewin's stories of lesbian mothers (1990).

18. While 12 women expressed very positive feelings, another 7 had mixed responses in terms of breastfeeding's impact on their body images; enjoying the nursing relationship, they expressed concern with weight gain, loss of prepregnancy shape, and the failure to achieve ideals of attractiveness and slimness. Maclean also found that cultural ideals for women's bodies make the breastfeeding experience less positive for some women (1990).

19. Of course, feminists have also vigorously debated what a liberatory, nonpatriarchal sexuality looks like, with some finding the "feminized" or difference-oriented ideal, based on women's greater intimacy and relationality, too repressed. See the collection in Vance, 1984.

\section{REFERENCES}

Andrews, Florence Kellner. 1991. "Controlling Motherhood: Observations on the Culture of the La Leche League." Canadian Review of Sociology and Anthropology, 28, No. 1: 84-98.

Bernard, Jessie. 1989. "The Good Provider Role: Its Rise and Fall." In Men's Lives, ed. M. S. Kimmel and M. A. Messner. New York: Macmillan.

Biernat, Monica, and Camille Wortman. 1991. "Sharing of Home Responsibilities Between Professionally Employed Women and Their Husbands." Joumal of Personality and Social Psychology 60(6): 844-860.

Block, Fred. 1990. Postindustrial Possibilities. Berkeley and Los Angeles: University of California Press.

Blum, Linda M. Forthcoming. "Mothers, Babies, and Breastfeeding in Late Capitalist America." Feminist Studies.

Blum, Linda M. with Elizabeth A. Vandewater. 1993. "Mother to Mother": A Maternalist Organization in Late Capitalist America." Social Problems, forthcoming.

Bly, Robert. 1990. Iron John. New York: Addison-Wesley.

"Breastfeeding Rights Packet." 1986. Franklin Park, IL: La Leche League International, Publication No. 78.

Brighton Argus. 1991. "La Leche League Sets Meeting for September." August 14, p. A-7. Brighton, Michigan.

Bumgarner, Norma Jane. 1982. Mothering Your Nursing Toddler. Franklin Park, IL: La Leche League International.

Cancian, Francesca. 1986. "The Feminization of Love." Signs 11(4): 692-709.

Chodorow, Nancy. 1978. The Reproduction of Mothering. Berkeley: University of California Press.

Connell, Robert W. 1990. "A Whole New World: Remaking Masculinity in the Context of the Environmental Movement." Gender \& Society 4(4): 452-478. 
Connell, R. W., N. Radican, P. Martin. 1989. "The Changing Faces of Masculinity." In Men's Lives, eds. M. S. Kimmel and M. A. Messner. New York: Macmillan.

Dana, Nancy and Anne Price. 1987. The Working Woman's Guide to Breastfeeding. New York: Meadowbrook (distributed by La Leche League International).

Davidman, Lynn. 1991. Tradition in a Rootless World. Berkeley: University of California Press.

Ehrensaft, Diane. 1990a. Parenting Together. Urbana and Chicago: University of Illinois Press.

Ehrensaft, Diane. 1990b. "Feminists Fight (for) Fathers." Socialist Review, 20(4); 57-80.

Eitzen, S. and M. Baca Zinn, eds. 1989. The Reshaping of America. Englewood Cliffs, NJ: Prentice Hall,

Fildes, Valerie. 1986. Breasts, Bottles, and Babies: A History of Infant Feeding. Edinburgh, UK: Edinburgh University Press.

Ginsburg, Faye. 1989. Contested Lives. Berkeley: University of California Press.

Gorham, Deborah and Florence Kellner Andrews. 1990. "The La Leche League: A Feminist Perspective." In Delivering Motherhood: Matemal Ideologies and Practices in the 19th and 20 th Centuries, edited by K. Arnup, A. Levesque, and R. R. Pierson. London and New York: Routledge.

Hartmann, Heidi. 1987. "Changes in Women's Economic and Family Roles in Post-World War II United States." In Women, Households, and the Economy, edited by L. Beneria and C. Stimpson. New Brunswick, NJ: Rutgers University Press.

Hayghe, Howard. 1986. "Rise in Mothers Labor Force Activity Includes With Infants." Monthly Labor Review, 109: 43-45.

Hochschild, Arlie. 1989. The Second Shift. New York: Viking Press.

Hunter, James D. 1987. Evangelicalism: The Coming Generation. Chicago: University of Chicago Press.

Kahn, Robbie Pfeufer. 1989. "Mother's Milk: The 'Moment of Nurture' Revisited." Resources for Feminist Research, 18(3): 29-36.

Kandiyoti, Deniz. 1988. "Bargaining with Patriarchy." Gender \& Society 2(3): 274-90.

Kaufman, Debra R. 1991. Rachel's Daughters. New Brunswick, NJ: Rutgers University Press.

Kessler-Harris, Alice, and Karen B. Sacks. 1987. "The Demise of Domesticity in America." In Women, Households, and the Economy, eds. L. Beneria and C. Stimpson. New Brunswick, NJ: Rutgers University Press.

Kilborn, Peter. 1992. "The Middle Class Feels Betrayed, But Maybe Not Enough to Rebel." New York Times, January 12, 4-1.

Kimmel, Michael S. 1992. "Reading Men: Men, Masculinity, and Publishing." Contemporary Sociology 21(2) 162-171.

Kuttner, Robert. 1992. "An Economics for Democrats." The American Prospect 8: 25-27.

Laqueur, Thomas. 1990. "The Facts of Fatherhood." In Conflicts in Feminism, eds. M. Hirsch and E. F. Keller. New York: Routledge.

Laslett, Barbara. 1992. "Feminism, Families, and Family Sociology." Typescript, University of Minnesota.

Lewin, Ellen. 1990. "Claims to Motherhood: Custody Disputes and Matemal Strategies." In Uncertain Terms: Negotiating Gender in American Culture, eds. F. Ginsburg and A. L. Tsing. Boston: Beacon.

LLLI. 1987, 1981, 1963. The Womanly Art of Breastfeeding. Franklin Park, IL: La Leche League International.

Lofton, Mary and Gwen Gotsch. 1983. "Legal Rights of Breastfeeding Mothers: USA Scene." Franklin Park, IL: La Leche League International, Reprint No. 59.

Lowman, Kaye. 1984. Of Cradles and Careers: A Guide to Reshaping Your Job to Include a Baby in Yout Life. Franklin Park, IL: La Leche League International.

Maclean, Heather. 1990. Women's Experience of Breastfeeding. Toronto: University of Toronto Press.

Mason, Karen O. and Yu-Hsia Lu, 1988. "Attitudes Toward Women's Familial Roles: Changes in the US, 1977-1985." Gender \& Society, 2, No. 1: 39-57.

Merrill, Elizabeth Bryant. 1987. "Learning How to Mother : An Ethnographic Investigation of an Urban Breastfeeding Group." Anthropology \& Education Quarterly, 18: 222-240. 
New Beginnings: La Leche League's Breastfeeding Journal. (Bimonthly members' magazine.) Vol. 6, 4, July-August 1990 to Vol. 9, 3, May-June 1992.

Newman, Katherine. 1988. Falling From Grace. New York: Free Press.

Parsons, Talcott and Robert Bales. 1953. Family, Socialization, and Interaction Process. New York: Free Press.

Pleck, Joseph. 1989. "The Contemporary Man." In Men's Lives, ed. M. Kimmel and M. Messner. New York: Macmillan.

Rossi, Alice. 1977. "A Biosocial Perspective on Parenting." Daedalus, 106: 1-31.

Rothman, Barbara Katz. 1989. Recreating Motherhood: Ideology and Technology in a Patriarchal Society. New York: W. W. Norton.

Ruddick, Sara. 1990. "Thinking about Fathers." In Conflicts in Feminism, ed. M. Hirsch and E. F. Keller. New York: Routledge.

Ryan, Alan S., David Rush, Fritz Krieger, and Gregory Lewandowski. 1991. "Recent Declines in Breastfeeding in the United States, 1985 through 1989." Pediatrics, 88(4) 719-727.

Sears, Robert R. and Deborah Lapidus. 1973. "Episodic Analysis of Novels." Journal of Psychology 85: 267-276.

Sears, William. 1983. Becoming A Father: How to Nurture and Enjoy Your Family. Franklin Park, IL: La Leche League International.

Seccombe, Wally. 1986. "Patriarchy Stabilized: The Construction of the Male Breadwinner Wage Norm in Nineteenth-century Britain." Social History 11(1): 53-76.

Segal, Lynne. 1990. Slow Motion: Changing Masculinities, Changing Men. New Brunswick, NJ: Rutgers University Press.

Stacey, Judith. 1990. Brave New Families. New York: Basic.

Stanworth, Michelle. 1990. "Birth Pangs: Conceptive Technologies and the Threat to Motherhood." In Conflicts in Feminism, eds. M. Hirsch and E. F. Keller. New York: Routledge.

Tamm, Merike. 1987. "And Then Came Aleksander." In Learning a Loving Way of Life, eds. V. Halonen and N. Mohrbachen. Franklin Park, Il: La Leche League International,

Thornton, Arland, Duane Alwin, and Donald Camburn. 1983. "Causes and Consequences of Sex-Role Attitudes and Attitude Change." American Sociological Review, 48: 211-227.

Trimm-Harrison, Mary. 1991. "A Time of Turmoil." New Beginnings, 8, No. 5 (September-October 1991): 153-154.

Vance, Carol, ed. 1984. Pleasure and Danger: Exploring Female Sexuality. Boston: Routledge \& Kegan Paul.

U.S. Department of Labor. 1987. News Bulletin, 87.345 (August).

U.S. Department of Labor. 1990. "Marital and Family Characteristics of the Labor Force from the March 1990 Current Population Survey." Typescript, October.

Van Esterik, Penny. 1989. Beyond the Breast-Bottle Controversy. New Brunswick, NJ: Rutgers University Press.

Weitzman, Lenore. 1985. The Divorce Revolution. New York: Free Press.

Wright, E. O., K. Shire, S. Hwang, M. Dolan, and J. Baxter. 1992. "The Non-effects of Class on the Gender Division of Labor In the Home." Gender \& Society 6(2): 252-282. 